\title{
Post Remediation Assessment of Residual Hydrocarbons in Contaminated Soil in Ogoni Using Gas Chromatographic Fingerprinting Technique and Phytotoxicity Bioassay
}

\author{
Leera Solomon $^{1 *}$, Chimezie Jason Ogugbue ${ }^{2}$ and Gideon Chijioke Okpokwasili
}

${ }^{1}$ Department of Science Laboratory Technology, School of Science and Technology, Captain Elechi Amadi Polytechnic, Rumuola, Nigeria

${ }^{2}$ Faculty of Science, Department of Microbiology, University of Port Harcourt, East-West Road, Nigeria

\begin{abstract}
Post-remediation assessment of residual total petroleum hydrocarbon (TPH) in an aged crude oil-contaminated soil (ACOCS) in Ogoni after seventy-day enhanced remediation by bio stimulation was investigated using gas chromatographic fingerprinting (GCF) technique and phytotoxicity bioassay. Seven treatments were designed and composted water hyacinth (EC), Mexican sunflower (TD) and Bermuda grass (CD) was applied as bio stimulants. Composted EC, TD or CD $(2,500 \mathrm{~g})$ was incorporated singly and in various combinations into $4,000 \mathrm{~g}$ of ACOCS in situ. Soil treatments consisted of TPA (un-amended), TPB (amended with EC), TPC (amended with TD), and TPD (amended with CD). Others include TPE (amended with EC and TD), TPF (amended with EC and CD) and TPG (amended with EC, TD and CD). There was significant $(\rho>0.05)$ reduction in total petroleum hydrocarbon (TPH) in TPG from 93,867 to $1,002 \mathrm{ppm}$ when compared to TPA which had TPH reduced from 98,673 to 79,583ppm. Gas chromatographic fingerprints of ACOCS before treatment indicated absence of $n$-alkanes within $n-C_{2}$ to $n$ - $C_{8}$ region which was attributed to weathering processes. However, after treatment with the substrates, carbon lengths $n-C_{9}$ to $n-C_{34}$ were significantly $(\rho>0.05)$ attenuated while those from $n-C_{35}$ to $n-C_{45}$ showed a decreasing tendency for enhanced attenuation thus, signifying their possible immobilization in particle pores. Seed germination index was $\geq$ $65 \%$, indicating that the remediated soil is non-phytotoxic and could support plant growth.
\end{abstract}

Keywords: Post-remediation; Ogoni; Residual hydrocarbons; Bio stimulation; Phytotoxicity

\section{Introduction}

Total petroleum hydrocarbon (TPH) is a term used for any mixture of hydrocarbons that are found in crude oil. It is comprised of a very large family of several hundred chemical compounds [1,2]. Petroleum hydrocarbons are of environmental interest because they are toxic to the human system, plants and animal resources $[3,4]$.

Yet, they pervade the environment beyond the vicinities of petroleum exploration and production activities due to storage, disposal and other handling activities during which contamination of the environment sometimes occur. Toxicity effects of total petroleum hydrocarbons in different environmental media have been studied [3-5]. The concentrations of total petroleum hydrocarbons recorded in an aged crude oil-contaminated soil in Yorla, Ogoniland have been reported [6] to be above the Department of Petroleum Resources (DPR)/Environmental Guidelines and Standards for the Petroleum Industries in Nigeria (EGASPIN) intervention limit of $5000 \mathrm{mg} / \mathrm{kg}$ [7].

Gas chromatographic fingerprinting requires using a gas chromatograph in analyzing the oil for hydrocarbon fractions in the spilled oil [2]. It is a representation of the relative concentration of compounds present in hydrocarbons. It has been demonstrated by Solomon et al. [8] that enhanced remediation of crude oil-contaminated soil using plant-based organic biomasses that is comprised of composted Eichhornia crassipes, Tithonia diversifolia and Cynodon dactylon as biostimulant could lead to a significant $(\rho>0.05)$ reduction in the residual concentration of hydrocarbons in the soil. Combinations of different bio stimulants followed by tilling gave a drastic reduction of TPH content from $93,867 \mathrm{ppm}$ obtained on day 0 to $1,002 \mathrm{ppm}(99 \%$ loss) after 70-day. The data is in agreement with the DPR/EGASPIN target value of $50 \mathrm{mg} / \mathrm{kg}$ [7].

Phytotechnology is a set of technologies using plants (roots, shoots, tissues, and leaves) to remove, transfer, stabilize, or destroy contaminants in media. Phytoremediation is an in situ technique that uses plants and/or its parts to restore contaminated media $[9,10]$. It applies to all biological, chemical, and physical processes that are influenced by plants that aid the cleanup of contaminated media. Plants materials aid degradation of organic pollutants directly or indirectly by supporting microbial growth [11-13].

Their roots are responsible for absorption and accumulation of hydrocarbon contaminants in soil [14]. Crude oil concentration in crude oil polluted soil affected plant growth and particularly the root lengths more than other parts [15]. The bioassay is useful in the evaluation of:

(i) The toxic effects of crude oil pollutants on plants and

(ii) The changes in the soil effect on plants after remediation measures $[15,16]$.

The research, therefore, was aimed at post-remediation assessment of the residual hydrocarbons present in an aged crude oil-contaminated soil after 70-days remediation by bio stimulation using both gas chromatographic fingerprinting technique and phytotoxicity bioassay.

"Corresponding author: Leera Solomon, Department of Science Laboratory Technology, School of Science and Technology, Captain Elechi Amadi Polytechnic, Rumuola, Nigeria, Tel: +2348067973111; E-mail: sololeera@yahoo.com

Received April 13, 2018; Accepted May 30, 2018; Published June 03, 2018

Citation: Solomon L, Ogugbue CJ, Okpokwasili GC (2018) Post Remediation Assessment of Residual Hydrocarbons in Contaminated Soil in Ogoni Using Gas Chromatographic Fingerprinting Technique and Phytotoxicity Bioassay. J Pet Environ Biotechnol 9: 367. doi: 10.4172/2157-7463.1000367

Copyright: (c) 2018 Solomon L, et al. This is an open-access article distributed under the terms of the Creative Commons Attribution License, which permits unrestricted use, distribution, and reproduction in any medium, provided the original author and source are credited. 
Citation: Solomon L, Ogugbue CJ, Okpokwasili GC (2018) Post Remediation Assessment of Residual Hydrocarbons in Contaminated Soil in Ogoni Using Gas Chromatographic Fingerprinting Technique and Phytotoxicity Bioassay. J Pet Environ Biotechnol 9: 367. doi: 10.4172/21577463.1000367

Page 2 of 5

\section{Materials and Methods}

\section{Sample collection}

Five grams (5 g) each of composite crude oil-contaminated soil samples was weighed form the seven (7) bio-treatment plots which included the control set-up into clean, dry beakers. Whole green plant samples of water hyacinth, Mexican sunflower and Bermuda grass were collected, composted in container and allowed to decay for two weeks.

\section{Bio stimulation treatment plots}

Seven bio-treatment plots were set-up with an area of $50 \mathrm{~m} \times 50 \mathrm{~m}$ marked out on each of the plot site. Seven treatment plots (TPA, TPB, TPC, TPD, TPE, TPF, and TPG) each containing $4000 \mathrm{~g}$ of ACOCS were used for this experiment. TPA contained ACOCS only and without amendment.

The TPA served as control and served as control to simulate natural attenuation processes $[11,13]$. Furthermore, TPB, TPC and TPD setups were stimulated singly with $2500 \mathrm{~g}$ of composted water hyacinth (Plot B), Mexican sunflower (Plot C) and Bermuda grass (Plot D) respectively. TPE, TPF and TPG were supplemented in with $2500 \mathrm{~g}$ of composted plant biomass of water hyacinth and Mexican sunflower (Plot E).

Plot $\mathrm{F}$ contained water hyacinth and Bermuda grass while Plot $\mathrm{F}$ has water hyacinth, Mexican sunflower and Bermuda grass combined. The treatments were monitored for hydrocarbon biodegradation as reported by Solomon et al. [11,13].

\section{Crude oil extraction from soil and gas chromatographic analysis}

Five grams ( $5 \mathrm{~g})$ of homogenized soil samples were accurately weighed into clean, dry beakers. The weighed samples were extracted with $10 \mathrm{ml}$ of hexane respectively and passed through a filter paper [17-19].

The extract (hydrocarbon/hexane mixture), now ready for gas chromatography, was injected into a Varian model 3400 gas chromatograph (GC) with the following operational conditions; flow rate $\left(\mathrm{H}_{2} 30 \mathrm{ml} / \mathrm{min}\right.$, air $300 \mathrm{ml} \mathrm{min}$ and $\left.\mathrm{N}_{2} 30 \mathrm{ml} / \mathrm{min}\right)$; injection temperature $\left(50^{\circ} \mathrm{C}\right)$, detector temperature $\left(320^{\circ} \mathrm{C}\right)$; recorders' voltage (IMV); and chart speed $1 \mathrm{~cm} / \mathrm{min}$. For interpretation of results, the gas chromatogram recorder was interfaced to a Hewlett Parker (hp) Computer (6207AA Software, Kaya XA PIT/350 W/48 megabytes CDROM). The chromatograms were quantified with respect to internal standards [20-22].

\section{Phytotoxicity bioassay}

Seed germination bioassay of remediated soil was carried out using lettuce plant seed ( $L$. sativum). Ten grams $(10 \mathrm{~g})$ of remediated aged crude oil-contaminated soil was collected from the 7 treatment plots and suspended in $100 \mathrm{ml}$ of distilled water in transparent test plates. The mixture was vigorously shaken for $30 \mathrm{~min}$ and the supernatants collected for seed germination bioassay $[23,24]$.

Microcosm was set set-up in "transparent test plates" and incubated vertically for $72 \mathrm{~h}$ at $25 \pm 2^{\circ} \mathrm{C}$ in the dark to allow the roots of the germinated seeds to be seen. Percentage germination index (GI\%) of the plant seed was calculated from the number of germinated seeds and root length elongation of $5 \mathrm{~mm}$ values in the TPA as well as in the bioremediated treatment plots. The germination index (GI\%) was evaluated using the expression:

$$
\mathrm{GI} \%=\frac{G s \times L s}{G c \times L c} \times 100
$$

Where,

Gs is the number of germinated seeds in the bioremediated soil,

Gc is the number of germinated seeds in un-amended control soil,

Ls is the average of root lengths in the bioremediated treatment soil,

Lc is the average of root lengths in the un-amended control treatment soil.

\section{Statistical analysis of data}

Data obtained were subjected to statistical analysis to determine the significant difference among the data obtained using one-way analysis of variance (ANOVA). A value of $p>0.05$ was considered significant while $\mathrm{p}>0.05$ was considered not significant.

\section{Results and Discussion}

The concentrations of residual fractions of total petroleum hydrocarbon and polyaromatic aromatic hydrocarbons in the soil after post- remediation study period are shown in Figures 1 and 2 . Data obtained indicated that carbon lengths between $n-\mathrm{C}_{1}-n-\mathrm{C}_{8}$ were absent.

The absence of low molecular weight hydrocarbons in the treated sample could be attributed to natural attenuation processes of weathering [25-27]. Data showed the distribution of paraffins ranging

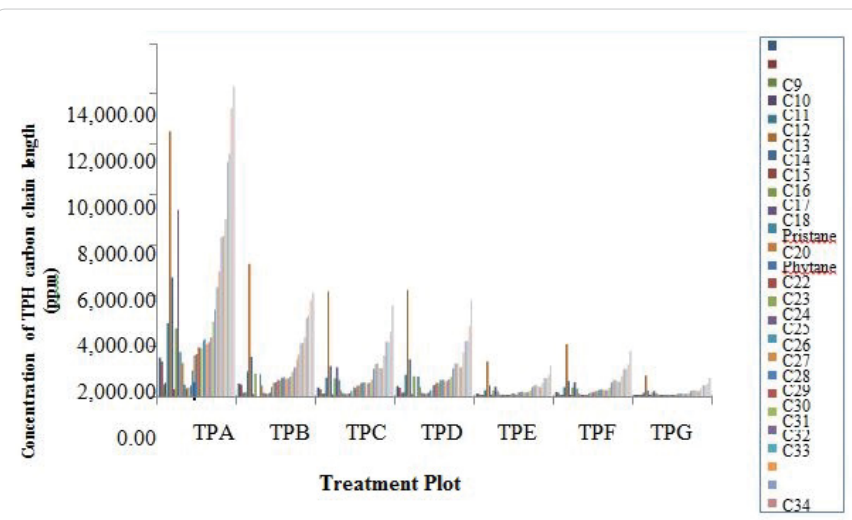

Figure 1: Concentrations of residual fractions of total petroleum hydrocarbon (TPH) in crude oil-contaminated soil during the study.

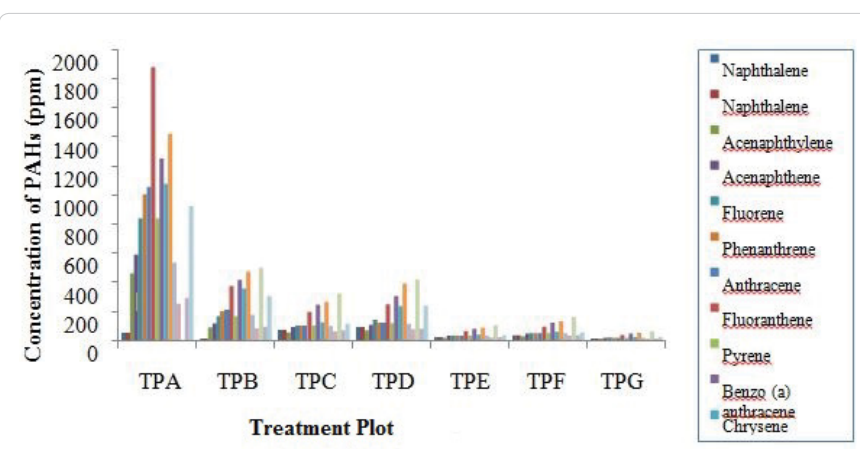

Figure 2: Concentrations of residual fractions of polycyclic aromatic hydrocarbons (PAHs) in the treatment during the study. 
Citation: Solomon L, Ogugbue CJ, Okpokwasili GC (2018) Post Remediation Assessment of Residual Hydrocarbons in Contaminated Soil in Ogoni Using Gas Chromatographic Fingerprinting Technique and Phytotoxicity Bioassay. J Pet Environ Biotechnol 9: 367. doi: 10.4172/21577463.1000367

from $n-\mathrm{C}_{9}$ to $n-\mathrm{C}_{23}$ with the fractions $n-\mathrm{C}_{9}, n-\mathrm{C}_{12}, n-\mathrm{C}_{13}, n-\mathrm{C}_{14}, n-\mathrm{C}_{15}$, $n-\mathrm{C}_{16}, n-\mathrm{C}_{18}$, pristane and $n-\mathrm{C}_{23}$ being relatively high in concentrations.

Carbon lengths between $n-\mathrm{C}_{9}$ to $n-\mathrm{C}_{34}$ were significantly $(\mathrm{p}>0.05)$ attenuated in the treatment plots, thus indicating that the residual crude oil in the soil environment was utilized by autochthonous microbes as sole source of carbon thereby resulting to its biodegradation $[28,29]$.

The samples also showed a distribution pattern of odd carbonnumbered alkanes being much abundant than even-numbered alkanes in the lower alkane range. Carbon fractions between $n-\mathrm{C}_{35}$ to $n-\mathrm{C}_{45}$ were not significantly $(\mathrm{p}<0.05)$ attenuated at the end of the study period, but was found to have exhibited a decreasing tendency for enhanced attenuation, thus, indicating the need for continuous nutrient supplementation, nutrient combination and possible extension of study duration.

The PAHs fractions was found to have been reduced in all treatment plots when compare to the control and this could be due to a combination of nutrient amendments added in the plot. Careful selection and combinations of different organic amendments could lead to a drastic attenuation of the heavy hydrocarbon fractions during enhanced remediation of crude oil-contaminated soil. The attenuation of these different hydrocarbon components as depicted by the trend in the disappearance of low-molecular-weight hydrocarbons from the various bio-treatment plots could probably be due to their preferential utilization by the autochthonous microorganisms in the contaminated soil environment $[29,30]$.

Gas chromatographic tracing of treatment plots indicated considerable residual hydrocarbon in the different attenuation of the various carbon fractions in the amended treatment when compared to the control, suggesting enhanced biodegradation of the crude oil in the soil.

Data obtained showed the pristane/phytane ratios of 3.80, 5.69, $4.83,5.30,4.82,4.83$ and 24.14 for TPA through TPG respectively and this depicted both artificial and petrogenic input. A pristane/phytane ratio of 5.70 has been reported by Osuji et al. [2] to be of plant/terrestrial source input and a possible toxic depositional environment. The $n-\mathrm{C}_{17} /$ pristane ratio of 1.53 was obtained for TPA while treatment plot B (TPB through TPG) had ratios that ranged from 1.02 to 1.11. Furthermore, $n-\mathrm{C}_{18}$ /phytane had ratios of 15.9 for TPA and TPB, 8.57, 9.39, 8.57 and 8.58 for TPC, TPD, TPF and ratio of 42.9 for TPG.

Figure 3 shows the structural characteristics of the various PAHs compounds in the soil environment. Members of the polyaromatic hydrocarbons (PAHs) include the following: Naphthalene, Naphthalene, Acenaphthylene, Acenaphthene, Fluorene, Phenanthrene, Anthracene, Fluoranthene, Pyrene, Benzo (a) anthracene, Chrysene, Benzo (b) fluoranthene, Benzo $(k)$ fluoranthene, Benzo $(a)$ Pyrene, Indo 1,2,3 cd Pyrene, Dibenzo $(a, b)$ anthracene and Benzo $(g h i)$ perylene [30,31].

The abundance of high-molecular-weight PAHs suggest that these hydrocarbon components were released from petrogenic source (i.e., from petroleum). The phenanthrene/ anthracene ratios obtained ranged from 0.95 to 1.02 , while the fluorathene/pyrene ratios ranged from 1.78 to 1.99 for the various treatments. Our results corroborated the report of Osuji et al. [2] who had similar phenanthrene/ anthracene and fluorathene/pyrene ratios of 0.95 and 2.23 respectively during their study on attenuation of petroleum hydrocarbons by weathering. The benzo (a) anthracene to chrysene ratios obtained in the various treatment plots ranged from 1.16 to 1.96 thus, confirming the nonpetrogenic origin of the petroleum hydrocarbon in the soil.

Advances in the development of gas chromatographic fingerprinting

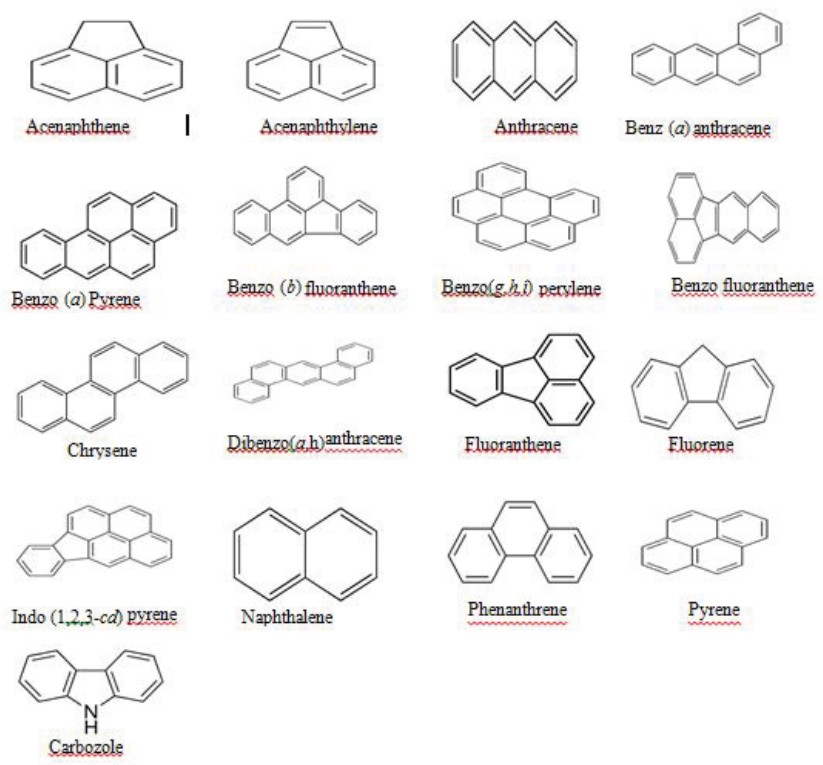

Figure 3: Structural characteristics of PAHs compound present in the soil environment.

(GCF) techniques will continue as analytical and statistical methods are developed. Hence it is believed that in the nearest future, these developments will further make gas GCF technique, a veritable tool for oil spill source identification and differentiation.

The trends in PAHs peak height attenuation could be attributed to the metabolic activities of PAH-degrading microbes which mediate the changing PAHs conditions in the soil as smaller molecules are being used to build larger ones and complex molecules broken down into smaller ones [20,28,30,32].

Data obtained indicated that there was no significant $(\mathrm{p}<0.05)$ reduction in PAHs concentration TPA but reduced significantly ( $>0.05$ ) in TPB through TPG following nutrient supplementation. Figures 4-6 show the GCF peaks heights of TPH and PAHs in TPA, TPB, TPC, TPD, TPE, TPF and TPG after the 70-day study.

This suggested that the crude oil was not only slightly weathered but biodegraded by hydrocarbon utilizing microbes, as corroborated by the number of peaks in the total petroleum hydrocarbon fingerprints. The GCF data obtained show various carbon lengths and PAHs components with decreasing peaks values (Figures 4-6) indicating presence of hydrocarbons from petroleum origin. Phytotoxicity bioassay has been described as an intoxication of living plants by substances in the growth medium, when these substances are accumulated in plant tissue [32,33]. The germination index (GI) of L. sativum obtained in the bio remediated soil followed a similar order as residual total hydrocarbon reduction in the treated plots. The phytotoxic capacity of the remediated soil after 70-day enhanced remediation study period via bio stimulation with plan-based manures indicated a gradual disappearance of phytotoxicity in the various bio-treatment plots (TPB through TPG) thus, indicating a significant $(\mathrm{p}>0.05)$ reduction of $\mathrm{TPH}$ in the TPG-amended treatment plot.

The pristine soil used as negative control, showed no toxicity to seed germination and is thought to contain only biogenic hydrocarbons. The seeds did not germinate at the onset of the test on $0 \mathrm{~d}$ in all treatments 
Citation: Solomon L, Ogugbue CJ, Okpokwasili GC (2018) Post Remediation Assessment of Residual Hydrocarbons in Contaminated Soil in Ogoni Using Gas Chromatographic Fingerprinting Technique and Phytotoxicity Bioassay. J Pet Environ Biotechnol 9: 367. doi: 10.4172/21577463.1000367

Page 4 of 5

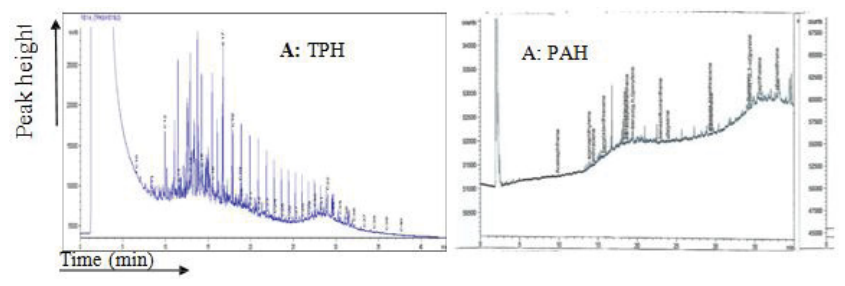

Figure 4: GCF of residual TPH and PAHs components in TPA after 70D remediation study.

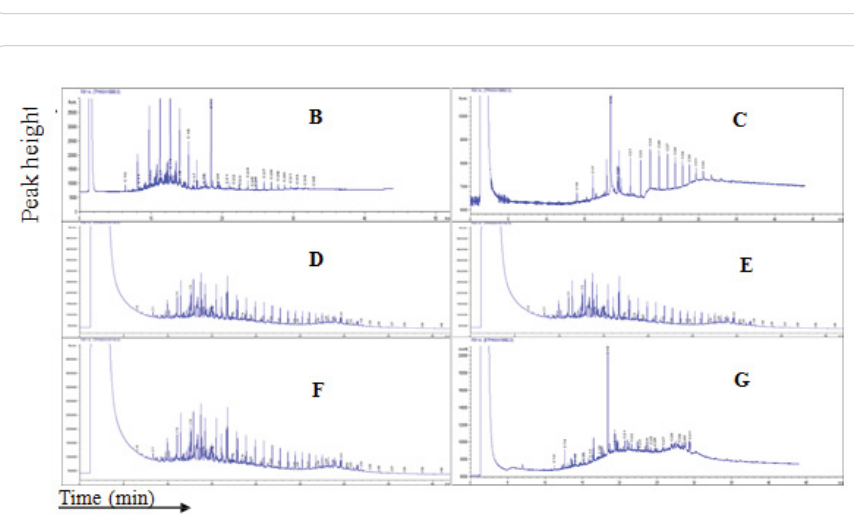

Figure 5: GCF of residual TPH in treatment plots B, C, D, E, F and G after $70 D$ remediation.

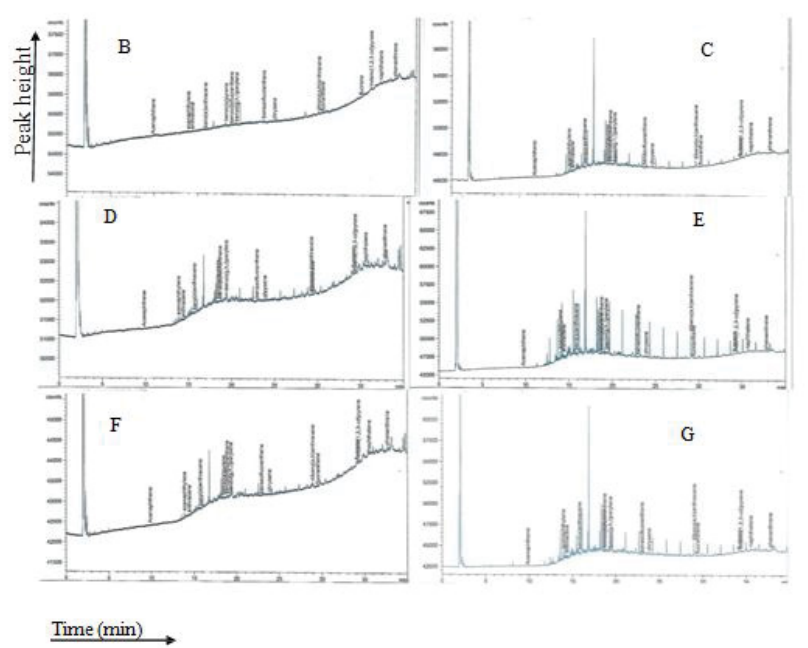

Figure 6: GCF of residual PAHs in treatment plots B, C, D, E, F and G after $70 \mathrm{D}$ remediation

but after 70-days of phytotoxicity testing, all the seeds germinated maximally in the treated soil, indicating no toxic effect of the residual crude oil in the soil after remediation [34].

Figure 7 indicated GI of $0.11 \%$ in the un-amended TPA, 65\% in TPB-amended with water hyacinth, $76 \%$ in TPC amended with Mexican sunflower and $71 \%$ in TPD-amended with Bermuda grass respectively. Whereas the GI of TPD amended with water hyacinth and Mexican sunflower was $91 \%$ while TPE-amended with water hyacinth and Bermuda grass recorded $83 \%$ while TPG-amended with all three nutrients of water hyacinth, Mexican sunflower and Bermuda grass had

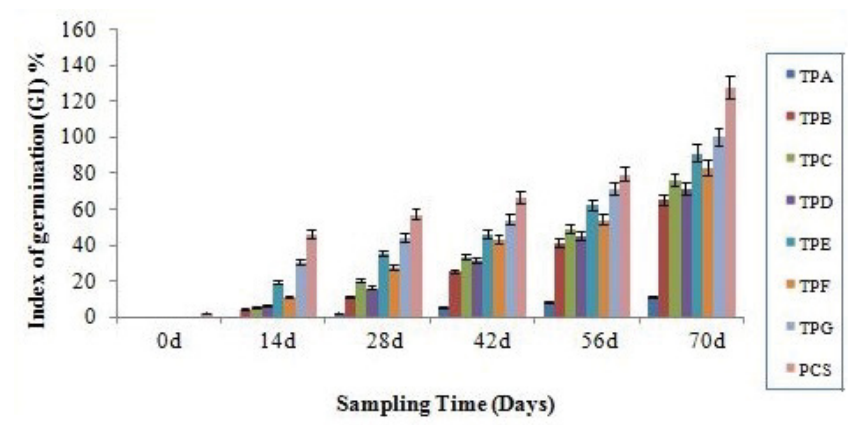

Figure 7: Index of germination of Lettuce plant (Lepidium sativum) seeds in the different treatment plots.

germination index (GI) of 100\%, thus indicating no toxic effect and biosafety of the crude oil pollutants on plant growth.

A GI less than $40 \%$ has been proposed to indicate a high toxicity while a value ranging from $40 \%$ to $60 \%$ indicates moderate toxicity (with delay in the seed germination) and values higher than $60 \%$ indicates the absence of any negative effect [35-38]. The results obtained indicated that TPA had GI of $0.11 \%$, giving high toxicity effect and could be probably due to the absence of nutrient amendments in the control set-up.

\section{Conclusion}

Advances in gas chromatographic fingerprinting technique allowed for detailed qualitative and quantitative characterization of spilled petroleum hydrocarbon and subsequent source identification. Phytotoxicity endpoints are useful indicators for the assessment of the quality of an environmental medium as a habitat for micro-fauna and flora.

It is generally useful in checking for toxicant concentrations that are bioavailable for adapted microbial species and other exogenous organisms in the crude oil-contaminated soil environment. The bio remediated soil could be considered non-phytotoxic and ecologically safe (without toxic impacts on seed germination) since the germination index of L. sativum in treated plot ranged between 65 and 100\%. Data obtained confirmed the remediated soil's recovery potential and biosafety level to ecotype. Plant-based organic manures used in this study are potent bio stimulating agents.

\section{Acknowledgments}

The authors are grateful to Dr. Lucky Akhenemhen and staff of Mitawave Services Limited, Port Harcourt for analyzing their soil samples for total hydrocarbons and Mr. Neekpoa Deekor for providing security during the study period. Mr. Bodo Prince Friday is also acknowledged for facilitating this work.

\section{References}

1. Boehm DS, Douglass PD, Bence GS, Burns AE, Mankiewiczl WA (1996) The natural petroleum hydrocarbon background in subtidal sediments of Prince William Sound, Alaska, USA. Environ Toxicol Chem 15: 1266-1281.

2. Osuji LC, Udoetok IA, Ogali RE (2006) Attenuation of petroleum hydrocarbons by weathering: A case study. Chem Biodivers 3: 422-433.

3. Saterbak A, Toy RJ, Wong DCL, McMain BJ, William MP (1999) Ecotoxicological and analytical assessment of hydrocarbon-contaminated soils and application to ecological risk assessment. Environ Toxicol Chem 8: 1591-1607.

4. Chukwujindu MA, Iwegbue, Williams ES, Nwajei GE (2008) Characteristic levels of total petroleum hydrocarbon in soil profiles of automobile mechanic waste dumps. J Soil Sci 3: 48-51.

5. Iwegbue CMA, Nwajei GE, Arimoro FO (2007) Characteristic levels of total 
Citation: Solomon L, Ogugbue CJ, Okpokwasili GC (2018) Post Remediation Assessment of Residual Hydrocarbons in Contaminated Soil in Ogoni Using Gas Chromatographic Fingerprinting Technique and Phytotoxicity Bioassay. J Pet Environ Biotechnol 9: 367. doi: 10.4172/21577463.1000367

Page 5 of 5

petroleum hydrocarbon in soil profiles of automobile mechanic waste dumps. Pak J Sci Ind Res 50: 247-250.

6. Onyema MO, Osuji LC, Solomon L (2013) Distribution of Petroleum Hydrocarbons in Post-burn Oil-impacted Site in Niger Delta. Lagos State, Nigeria. J Appl Sci Environ Manage 19: 719-724.

7. Ibekwe SE, Okpokwasili GC (2002) Department of Petroleum Resources. EGASPIN 4: 13-20.

8. Solomon L, Ogugbue CJ, Okpokwasili GC (2018) Efficacy of locally sourced plant-based organic biostimulants on enhanced in situ remediation of an aged crude oil-contaminated soil in Yorla, Ogoniland. Afr J Microbiol Res 6: 33-45.

9. Alkorta I, Garbisu C (2001) Phytoremediation of organic contaminants in soils. Bioresour Technol 79: 273-276.

10. Ashton PJ, Mitchell DS (1989) Aquatic plants: Patterns and mode of invasion, attributes of invading species and assessment of control programs. Biological invasions: A global perspective. John Wiley and Sons, New York, USA.

11. Ogugbue CJ, Mbakwem-Aniebo C, Solomon L (2017) Efficacy of brewery spent grain and rabbit droppings on enhanced ex situ bioremediation of an aged crude oil contaminated soil. Int J Appl Microbiol Biotechnol Res 5: 27-39.

12. Solomon L, Ogugbue CJ, Mbakwem-Aniebo C (2018) Exploring the potentials of nipa palm (Nypa fruticans) ash and rabbit droppings for enhanced ex situ bioremediation of crude oil-contaminated soil. Asian J Biotechnol Biores Tech 3: 1-17.

13. Solomon L, Ogugbue CJ, Okpokwasili GC (2018) Inherent bacterial diversity and enhanced bioremediation of an aged crude oil- contaminated soil in Yorla, Ogoniland using composted plant Biomass J Adv Microbiol 9: 1-16.

14. Araujo ASF, Monteiro RTR (2005) Plant bioassays to assess toxicity of textile sludge compost. Sci Agric 62: 286-290.

15. Zucconi F, Forte M, Monac A, Beritodi M (1981) Biological evaluation of compost maturity. Biocycle 22: 27-29.

16. Bartha R (1986) Biotechnology of petroleum pollutant biodegradation. FEMS Microbiol Ecol 12: 155-172.

17. Black CA (1965) Methods of soil analysis. American Society of Agronomy 9: $12-15$

18. Stout SA, Uhler AD, McCarthy KJ, Emsbo-Mattingly S (2002) Chemica fingerprinting of hydrocarbons. In: B.L. Murphy and RD Morrison Introduction to environmental forensics. London: Academics, UK. pp: 137-260.

19. Wang Z, Fingas MF (2003) Development of oil hydrocarbon fingerprinting and identification techniques. Mar Pollut Bull 47: 423-452.

20. Onianwa PC, Essien CA (1999) Petroleum hydrocarbon levels in sediments of stream and river within Ibadan city, Nigeria. B Chem Soc Ethiopia 13: 82-85.

21. Sadler R, Connell D (2003) Analytical methods for determination of total petroleum hydrocarbon in soil. NEPC Service Corporation, Adelaide, Australia. pp 133-150.

22. Korda A, Sanatas P, Tenente A, Santas R (1997) Petroleum hydrocarbon bioremediation: sampling and analytical techniques in-situ treatment and commercial microorganisms currently used. Appl Microbiol Biotechnol 48 677-686.

23. Hunt JM (1996) Petroleum geochemistry and geology. Energy Fuels 47 415-437.

24. Solomon L, Daminabo V, Uzor CA (2016). A synoptic review on ecological toxicology and environmental sustainability. Researcher 8: 6-10.

25. Ogugbue CJ, Solomon L, Olali IN (2017) Enhanced biodegradation of petroleum hydrocarbons in polluted soil augmented with nitrogen-fixing bacteria. Life Sci J 14: 82-91.

26. Atlas RM (1997) Stimulated petroleum biodegradation. Crit Rev Microbiol 5 371-386.

27. Atlas RM (1981) Microbial degradation of petroleum hydrocarbons: an environmental perspective. Microbiol Mol Biol Rev 45: 180-209.

28. Huesemann MH (1995) Predictive model for estimating the extent of petroleum hydrocarbon biodegradation in contaminated soils. Environ Sci Technol 29 7-18.

29. Huesemann MH (1997) Incomplete hydrocarbon biodegradation in contaminated soils: limitations in bioavailability or inherent recalcitrance. Bioremediat J 1: 27-39.

30. Alexander M (2000) Aging, bioavailability and overestimation of risk from environmental pollutants. Environ Sci Technol 34: 4259-4265.

31. Ana REE, Sridhar MKC, Emerole GO (2009) A comparative assessment of soil pollution by polycyclic aromatic hydrocarbons in two Niger Delta communities, Nigeria. Afr J Pure Appl Chem 3: 31-41.

32. Akpahwe L, Solomon L (2012) Crude oil theft and its environmenta consequences: The way forward. Conference of the Nigerian Environmental Society, Nigeria.

33. Solomon L, George-West O, Alalib IK (2017) Environmental pollution in the Niger delta and consequential challenges to sustainable development of the region: The role of an individual. Researcher 9: 10-15.

34. Mbakwem-Aniebo C, Ogugbue CJ, Solomon L (2014) Petroleum industries in the Niger Delta: A critical overview of its environmental impacts and socioeconomic implications.

35. Ashokkumar K, Selvaraj K, Muthukrishnan SD (2013) Cynodon dactylon (L.) Pers: An updated review of its photochemistry and pharmacology. J Med Plant Res 7: 3477-3483.

36. Achieng JO, Ouma G, Odhiambo G, Muyekho F (2010) Effect of Tithonia diversifolia (Hemsley) and inorganic fertilizers on maize yield on alfisols and ultisols of Western Kenya. Agric Biol J N Am 1: 263-265.

37. Bhattacharya A, Kumar P (2010) Water hyacinth as a potential biofuel crop. Electron J Environ Agr Food Chem 9: 112-122.

38. Solomon L, Ogugbue CJ, Okpokwasili GC (2018) Influence of biostimulation treatment using composted plant biomass on bacterial diversity of an aged petroleum contaminated soil as determined by culture-dependent and $16 \mathrm{~S}$ rRNA gene PCR-DGGE based identification methods. South Asian J Res Microbiol 1-16. 